\title{
EXTRACTION AND CHARACTERIZATION OF NATURAL FIBRES FORM ELETTARIA CARDAMOMUM
}

\author{
Dr. Murugesan Sumithra ${ }^{1 *}$, Gayathri Murugan²
}

\author{
'Assistant Professor, Department of Textiles and Apparel Design, \\ Bharathiar University, Coimbatore, Tamilnadu, India \\ ${ }^{2}$ Ph.D. Scholar, Department of Textiles and Apparel Design, \\ Bharathiar University, Coimbatore, Tamilnadu, India \\ * e-mail: sumitad@buc.edu.in
}

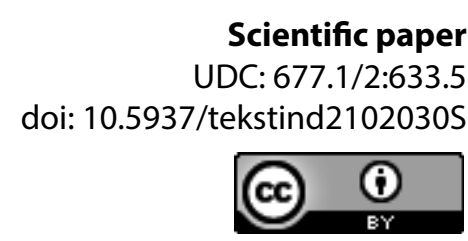

\begin{abstract}
Natural fibres are one of the good alternative sources for replacing synthetic fibres and reinforcing polymer matrices because of their eco-friendly nature. The present study was undertaken to investigate the fibres extract from Elettaria Cardamomum plant. The extracted Elettaria Cardamomum fibre was treated with $\mathrm{NaOH}$ for softening. Natural cellulose fibres extracted from Elettaria Cardamomum stems (ECS) have been characterized for their chemical composition and physical properties.The chemical composition of Elettaria Cardamomumstems (ECS) fibres is, cellulose $60.44 \%$, lignin $25.25 \%$, wax $0.53 \%$, ash $5.45 \%$. Regarding physical properties of the fibres, single fibre strength was evaluated and the result was compared with cotton fibre and linen fibre.
\end{abstract}

Keywords: Chemical composition, cotton fibre, Elettaria Cardamomum, natural fibres and physical properties.

\section{EKSTRAKCIJA I KARAKTERIZACIJA PRIRODNIH VLAKANA ELETTARIA CARDAMOMUM}

Apstrakt: Prirodna vlakna predstavljaju dobre alternativne izvore za zamenu sintetičkih vlakana i ojačanja polimenrih matrica usled njihove ekološke prirode. Predstavljeno istraživanje je sprovedeno da bi se ispitala vlakna ekstrahovana iz biljke Elettaria Cardamomum. Ekstrahovano vlakno Elettaria Cardamomum je tretirano sa $\mathrm{NaOH}$ radi omekšavanja. Prirodna celulozna vlakna ekstrahovana iz stabiljki Elettaria Cardamomum (ECS) su okarakterisana svojim hemijskim sastavom i fizičkim svojstvima. Hemijski sastav Elettaria Cardamomum (ECS) obuhvata celulozu $60.44 \%$, lignin $25.25 \%$, vosak $0.53 \%$ i pepeo $5.45 \%$. Što se tiče fizičkih svojstava, procenjena je čvrstoća pojedinačnih vlakana a rezultat je upoređen sa pamučnim i lanenim vlaknima.

Ključne reči: Hemijski sastav, pamučna vlakna, Elettaria Cardamomum, prirodna vlakna i fizička svojstva.

\section{INTRODUCTION}

Textiles have such an important bearing on our daily lives that everyone needs to know something about them. Natural fibres are that are produced by plants fabrics are light in weight, soft in texture, and which can be made in various sizes and colours [1]. Fibre is a natural or synthetic substance that is significantly longer than it is wide. The two main divi- sions in textile fibres are natural and man - made. Natural fibres are those found in nature already usable to make fabrics. The two main sources are plants and animals. Textile fibres may be staple or filament. Staple fibres are relatively short, measured in millimetres or inches. Filament fibres are relatively long, measured in meters or kilometres of yarns. Fibres are often used in the manufacture of other materials [2]. 
Eletaria Cardamomum, a tall perennial, reed-like plant that grows wild in the forests of Southern India, especially near the Malabar Coast. It is cultivated there as well as in Ceylon, the fruits of commerce being obtained from cultivated plants [3]. It is historically known as the "Queen of all Spices". It grows in the understory of tropical rain forests at elevations of $762-1524 \mathrm{~m}$, where it rains about $381 \mathrm{~cm}$ per year. It is cultivated commercially in India, Sri Lanka, Guatemala and Tanzania [4].

Retting is a process employing the action of micro-organisms and moisture on plants to dissolve or rot away much of the cellular tissues and pectin's surrounding new fibre bundles, and so facilitating separation of the fibre from the stem. It is used in the production of fibre from plant materials such as flax and hemp stalks and coir from coconut husks. The most widely practiced method of retting, water retting. Natural water retting employs stagnant or slow-moving waters, such as ponds, bogs, and slow streams and rivers. The stalk bundles are weighted down, usually with stones or wood, for about 8 to 14 days, depending upon water temperature and mineral content [5].

Softening is an important finishing process in printing and dyeing. In order to make the fabric soft and smooth, textile finishing process is required, and in this process, the most common used finishing agent is textile softener. According to the chemical structure, fabric softeners can be mainly divided into different categories. Many kinds of softening agent will be suitable for wool, silk, cotton, flax fibre and also for blended fabric [6]. Textile fibres are combed to remove short fibres, neps, vegetable and other impurities. The two most commonly used machines for combing fibres are the rectilinear combing machine and the Noble combing machine. Recently certain combinations of these machines have been proposed to incorporate the advantages of both machines into a single machine [7].

The objectives of the study are:

- Selection of ELETTARIA CARDAMOMUM for fibre extraction.

- Identification of fibre from ELETTARIA CARDAMOMUM by retting process.

- Evaluation of fibres physical, mechanical properties

- Comparative analysis of ELETTARIA CARDAMOMUM fibre properties with those of cotton and linen fibres.

\section{MATERIALS AND METHODS}

\subsection{Selection of plant}

The Elettaria Cardamomum plant was collected from Idukki in Kerala State. It is constituted of stems with a cylindrical shape which has a maximum height of about 4-5 feet. It was shown in Figure 1. The sample was washed with water and cut in a small piece, before extraction.

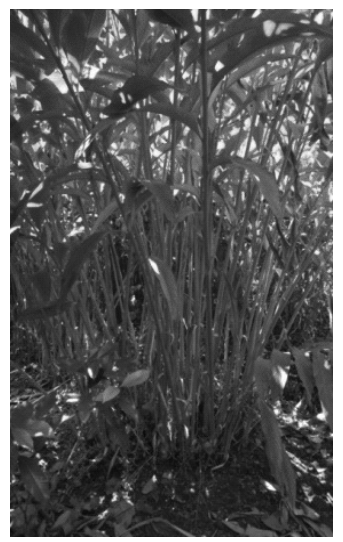

Figure 1: Elettaria Cardamomum plant

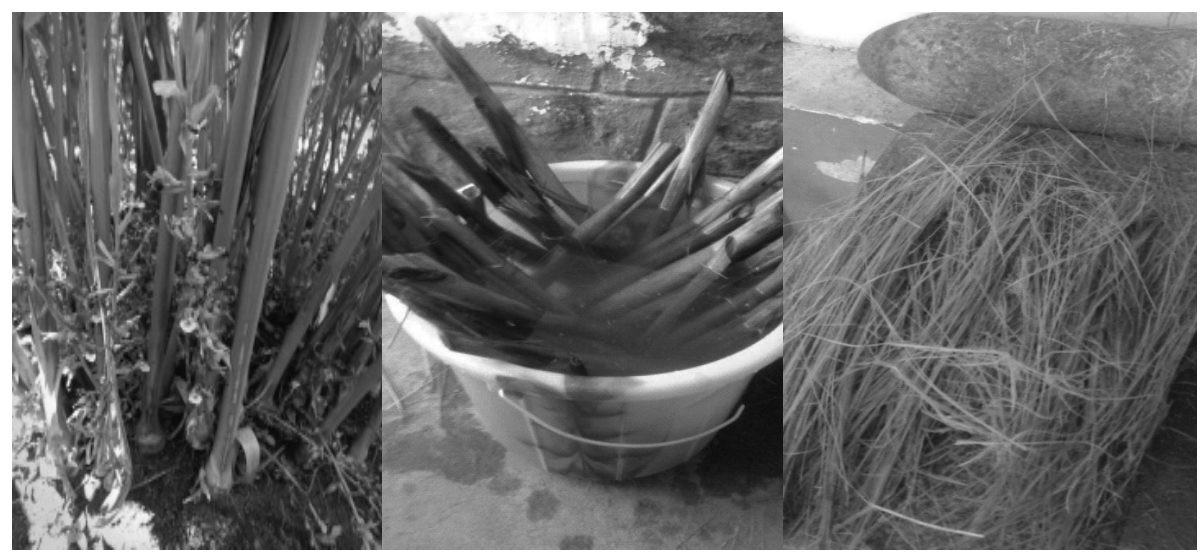

Figure 2: ECS

Figure 3:

Water Retting
Figure 4: Fibres 


\subsection{Extraction of fibre}

The fibres were extracted from ECS using the method of water retting process. Shown in Figure 2.

About 10 liters of water is taken in a bucket, and $5 \mathrm{~kg}$ of stem were cut in to small pieces (average length of $60 \mathrm{~cm}$ ) and immersed into it. It is kept it for 20 days under room temperature. After 20 days the stems are taken out from the water and beated with hammer for extracting the fibres separately. The separated fibres kept for one day on sunlight to remove the moisture from, obtained fibres are shown in Figure 3 and Figure 4.

\subsection{Softening of fibres}

Softening is the removal of lignin, calcium, as carbonate and the magnesium as hydroxide, whereupon sodium hydroxide is added to remove the remaining calcium salts. The $50 \mathrm{~g}$ of fibre was treated with $30 \%$ of $\mathrm{NaOH}$ solution with the material to liquor ratio 1:20 for $1 \mathrm{hr}$, after treatment the fibre was removed from the bath and washed thoroughly in distilled water and dried under sunlight.

\subsection{Combing process}

The softened fibres were placed on the combing board in flat to its surface. The steel hand comb was passed through the fibres and combed it neatly. By doing this process short fibres were collected on the face side of the comb. The processes ere repeated till the getting of fine and good quality fibre.

\subsection{Chemical composition determination}

To determine the composition of fibres we have to apply chemical test. Because there may consist of both thermoplastic and non-thermoplastic fibres. But in chemical test if it dissolves in a specific chemical, we can identify that fibre. Now if we weight the sample before dissolving in chemical and after dissolving in chemical, we can easily find out the composition of them in the fabric sample. At last, we will apply chemical for the rest fibres to identify it. Suppose the total weight of the fabric sample $=a$ and after dissolving one portion we find the rest weight $b$.

\section{Then we can find the composition as follow:}

- Fibre composition of $1 \mathrm{st}=(a-b) / a \times 100 \%$

- Fibre composition of $2 n d=b / a \times 100 \%$

\subsection{Physical properties determination single fiber strength}

The strength of any material is derived from the load it supports at break and is thus a measure of its limiting load bearing capacity. Normally strength of a textile fibre is measured in tension when the fibre is loaded along its long axis and is designated as Tensile strength. The strength and elongation of a fibre can be measured by a single fibre or by the bundle method. The bundle fibre strength can be measured using an ASTM standard test procedure that employs a fibre bundle tensile testing machine.

\section{RESULT AND DISCUSSION}

\subsection{Chemical composition testing}

\section{Fibre Chemical Composition}

The chemical composition of fibres depends on their origin. The chemical composition of a pure substance corresponds to the relative amounts of the elements that constitute the substance itself. Chemical Composition of ECS fibres before and after softening is given in Table 1.

Table 1: Fibre chemical composition

\begin{tabular}{|l|c|c|c|}
\hline \multicolumn{1}{|c|}{$\begin{array}{c}\text { Fibre Chemical } \\
\text { Composition }\end{array}$} & $\begin{array}{c}\text { Cardamomum } \\
\text { Stem Fibre }\end{array}$ & Cotton & Linen \\
\hline Cellulose Content \% & 60.44 & $85-90$ & $72-82$ \\
\hline Lignin Content \% & 25.25 & $0.7-$ & $2-3$ \\
\hline Wax Content \% & 0.53 & - & - \\
\hline Ash Content \% & 5.45 & $0.8-2.0$ & - \\
\hline Moisture Content \% & 8.03 & - & - \\
\hline Density kg/m3 & 1.16 & - & - \\
\hline
\end{tabular}

From the Table 1 it shows that the cellulose content is 60.44, which is less when compared to cotton and linen. Lignin content is 25.25 , which is more when compared to cotton and linen, and ash content is 5.45 , which is high when compared to cotton and linen. Wax content is 0.53 , ash moisture content is 8.03 and density is 1.16 .

On the whole it is concluded that when compared with Cardamomum Stem Fibre, cotton and linen fibre. The Cardamomum Stem Fibre has good chemical composition.

\subsection{Single fibre strength}

The strength of any material is derived from the load it supports at break and is thus a measure of its 
limiting load bearing capacity. Normally strength of a textile fibre is measured in tension when the fibre is loaded along its long axis and is designated as tensile strength. Obtained results are shown in Table 2.

Table 2: Single Fibre Strength Test

\begin{tabular}{|l|c|}
\hline $\begin{array}{c}\text { Single Fibre Strength and } \\
\text { Elongation } \\
\text { (Zwick /Roell) }\end{array}$ & $\begin{array}{c}\text { Cardamomum } \\
\text { Stem Fibre }\end{array}$ \\
\hline Mean Breaking Strength $\mathrm{F}_{\max }$ (gf) & 695 \\
\hline $\begin{array}{l}\text { Mean Breaking Elongation DI } \\
\text { at } \mathrm{F}_{\max }(\%)\end{array}$ & 1.1 \\
\hline
\end{tabular}

In Table 2, presented above, the mean value of Single fibre Strength $=695$ and Mean Elongation of fibre $=1.1$, when compared to cotton and linen the Cardamomum Stem Fibre has good value.

\section{CONCLUSION}

In this study, the Cardamomum plant were collected, then the fibres from cardamomum stem had been extracted using water retting method. The chemical composition and the physical properties of the extracted fibres were evaluated. The extracted fibres had good physical properties and fibre chemical composition. Hence based on the availability of plants and stem fibres could be extracted.

\section{REFERENCE}

[1] Sumithra, M. (2021). Identification of new natural fibre from chamaecostus cuspidatus. Tekstilna Industrija, 69(1), 17-20.

[2] Kadolph, S. (2002). Textiles. Prentice Hall. Upper Saddle River, NJ.

[3] Greenish, H. G. (1855), Anatomical atlas of vegetable powders designed as an aid to the microscopic analysis of powdered foods and drugs. London, Churchil.

[4] Aneja, K.R., Joshi, R. (2009), Antimicrobial Activity of Amomum subulatum and Elettaria cardamomum Against Dental Caries Causing Microorganisms, Ethnobotanical Leaflets, 13, 840-49.

[5] Retting, fibre separation process, Retrieved from Encyclopedia Britannica Online: http://www. britannica.com/EBchecked/topic/500159/retting available: 07.06.2021.

[6] https://www.htfine-chem.com/product/hand-feelsfinishing-agent/softener-series/available: 07.06.2021.

[7] https://nptel.ac.in/content/storage2/courses/ $116102038 /$ combing/introduction $\% 20$ to $\% 20$ combing.html available: 07.06.2021.

Primljeno/Received on: 12.02.2021.

Revidirano/ Revised on: 01.06.2021.

Prihvaćeno/Accepted on: 06.06.2021.

(c) 2021 Authors. Published by Union of Textile Engineers and Technicians of Serbia. This article is an open access article distributed under the terms and conditions of the Creative Commons Attribution 4.0 International license (CC BY) (https://creativecommons.org/licenses/by/4.0/) 